\title{
725 重力の影響を考慮に入れた弾性送水管曲管部の面内振動
}

Dynamics of a Curved Fluid-Conveying Pipe Taking the Gravity Force into Consideration

水成 徹次 (慶大院)
正 山下 清隆 (早大)
正 吉沢 正紹（慶大）

新谷 智史 (三菱重工)

Tetsuji MIZUNARI, Keio University, 3-14-1 Hiyoshi, Kohoku-ku, Yokohama

Masatsugu YOSHIZAWA, Keio University

Kiyotaka YAMASHITA, Waseda University

Tomofumi SHINTANI, Mitsubishi Heavy Industry

\begin{abstract}
This paper deals with the static shape and dynamics of a curved fluid-conveying pipe, which is hanging horizontally and is supported at both ends. First, the effects of the gravity force acting on the pipe, the tension at the supported ends and the fluid force of an internal flow on the static equilibrium state of the flexible curved pipe are clarified theoretically. Second, the forced in-plane vibration of the curved pipe due to the pulsating component of an internal flow is examined theoretically. Finally, the experiments were conducted with a silicon rubber tube conveying water.
\end{abstract}

Key Words: Vibration of Continuous System, Forced Vibration, Vibration Coupled with Fluid Motion

管内流による弾性送水管の振動問題は, 流体関連振動の基 礎的課題として多くの研究が行われてきた。しかし，弾性送 水管の曲管部の振動に関する研究は工業的に重要な問題を 含んでいるにもかかわらず，直管部の場合に比べ数少ない.

このような中, 著者らは一連の研究において, 曲管の空間 運動に着目し，その運動を記述する方程式系の誘導を行っ た. 誘導された方程式を元に，管内定常流速が管の固有振動 に与える影響を理論的・実験的に調べた。この結果は, Misra らの結果に帰着している. 一方, 弦やケーブルの振動問題で は，重力の影響により発生するたわみが弦やケーブルの不安 定現象に時として大きく作用することが報告されている.

本研究では，てれらの事を念頭に入れ，従来の鉛直に吊り 下げられた真っ直ぐな弾性送水管の方程式系の誘導を参考 にしながら，重力の影響を考虑に入れた弾性送水管の曲管部 の方程式系を導出する.

次に，重力の影響が曲管部の振動現象に及ぼす影響を明ら かにする最初のステップとして, 得られた支配方程式から時 間変動項を無視し，曲管の静的釣り合い状態を明らかにす る.そして, 重力が曲管の静的釣り合い状態に及ぼす影響を 検証する. その上で，面内強制振動の励振メカニズムに関し て理論解析を行う。

さらにシリコンチューブに水を流す実験を行い，定常流速 を変化させ,管の固有振動数の測定を行う.また，流速に脈 動流成分を付加し，その振動数を变化させることで, 曲管の 面内振動を実験的に確認する。

本研究で用いる解析モデルを図 A1 に示す．管軸に沿つ た座標を $s$ とし, 鉛直方向变位を $u(s, t)$, 水平方向変位を $w(s, t)$, 座標 $s$ での接線方向と鉛直方向とのなす角度を $\theta(s, t)$ とする. また，管内には非圧縮，一次元流れと仮定した密度 $\rho_{f}$ の流体が定常流速 vで管軸に沿って流れているとした。

本研究で理論解析により得られた結論を以下に示す。

・管内流による曲管の平面運動を，今まで考慮されていな かった静的釣り合い状態における重力の影響を考慮し， 管の中心軸は伸びないという仮定のもと, $u(s, t), w(s, t)$ および $\theta(s, t)$ で表される非線形の方程式で表した.
- 得られた方程式の時間変動項を無視し，静的釣り合い状 態を表す方程式を導出した. また， $\gamma=0$ のとき，管の 形状は管にかかる軸力を調節することで，管の両端間の 距離を直径とする半円形になることを確認した。

- 静的釣り合い状態を半円形とそれからの変動成分との和 で表し，その変動成分を積分形を含む線形変数係数の常 微分方程式で表した. 得られた方程式の解をべき級数展 開により求め, 重力が管の静的釣り合い状態に与える影 響を確認した。

- 管の面内自由振動について，管内定常流速が管の固有振 動に影響を与えることを明らかにした。 また，一次モー ドの振動形状を求めた。

- 管内脈動流による曲管の面内強制振動において $v$ が管の 固有振動数付近で振動振幅が最大となり，そのときの振 動モードは固有振動状態での解析結果とよく一致した。 実験により得られた結論は以下の通りである。

・自由振動実験により，曲管の振動モードを確認した。 ま た，管内定常流速の増加にともない，管の固有振動数は 減少するととを確認した。

- 曲管が脈動流成分と同じ振動数で振動することから，送 水管は管内に脈動流が流れることにより, 強制振動して いることを確認した.

- 脈動流成分の振動数が固有振動数付近において最も励振 された．また，そのときほぼ水平方向に振動しているこ とを確認した。

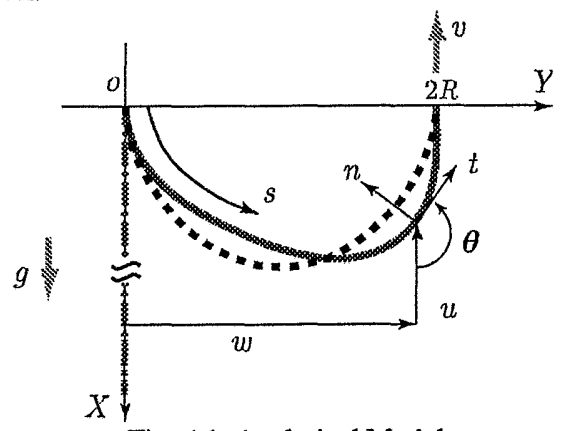

Fig. A1 Analytical Model

日本機械学会 [No.04-5] Dynamics and Design Conference 2004 CD-ROM論文集〔2004.9.27-30,東京〕 


\section{1. はじめに}

管内流による弾性送水管の振動問題は，流体関連振動の基 礎的課題として多くの研究が行われてきた. しかし, 弹性送 水管の曲管部の振動に関する研究は工業的に重要な問題を 含んでいるにもかかわらず，直管部の場合に比べ数少ない (1)(2)(3)(4).

このような状況の中で, 著者らは一連の研究において，管 の空間運動に着目し，その運動を記述する方程式系の誘導を 行った (5). 誘導された方程式を元に，管内定常流速が管の 固有振動に与える影響を理論的・実験的に調べた。この結果 は, Misra らの結果に帰着している(2)。一方，弦やケーブル の振動問題では，重力の影響により発生するたわみが弦や ケーブルの不安定現象に時として大きく作用することが報 告されている(6)

本研究では，これらの事を念頭に入れ，従来の鉛直に吊り 下げられた真っ直ぐな弾性送水管の方程式系の誘導を参考 にしながら，重力の影響を考慮に入れた弾性送水管の曲管部 の方程式系を導出する.

次に，重力の影響が曲管部の振動現象に及ぼす影響を明ら かにする最初のステップとして, 得られた支配方程式から時 間変動項を無視し，曲管の静的釣り合い状態を明らかにす る. そして，重力が曲管の静的釣り合い状態に及ぼす影響を 検証する. その上で, 面内強制振動の励振メカニズムに関し て理論解析を行う。

さらにシリコンチューブに水を流す実験を行い，定常流速 を变化させ,管の固有振動数の測定を行う。また，流速に脈 動流成分を付加し，その振動数を変化させることで，曲管の 面内振動を実験的に確認する.

\section{2. 解析モデルおよび支配方程式}

解析モデルを図 1 に示す．鉛直方向に $X$ 軸，水平方向に $Y$ 軸をとった固定座標系を考える. 弾性送水管の上端は原点 $O$ に固定され，鉛直に吊り下げられた状態から下端を $Y$ 軸 上に持ち上げて固定する. 管軸に沿った座標を $s$ とし， $X$ 軸 方向変位を $u(s, t), Y$ 軸方向変位を $w(s, t)$ 扔よび座標 $s$ での 接線と鉛直方向とのなす角度を $\theta(s, t)$ とする。

$X-Y$ 面内に拘束された弾性送水管を断面が一定で，中心 軸の伸びないはりとみなし，その単位長さあたりの質量を $m_{p}$, 断面積を $S_{p}$, 曲げ剛性を $E I$ とする，管内を流れる流体

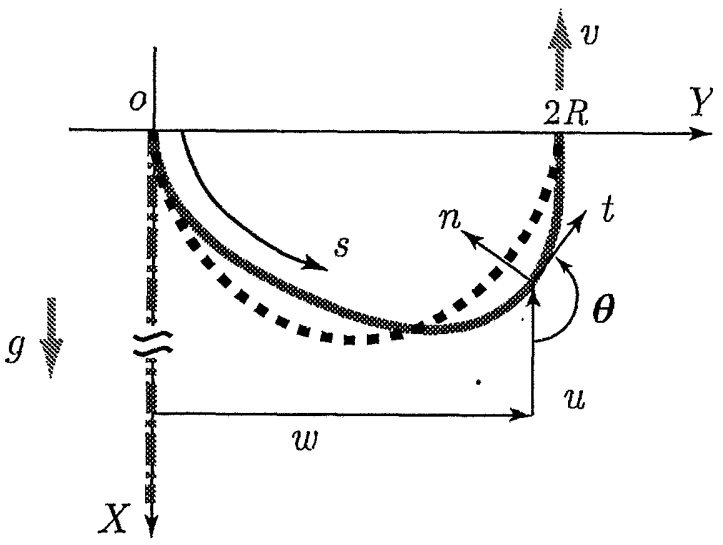

Fig.1 Analytical Model
の密度を $\rho_{f}$ とし，管軸に沿った流速を $v$ とする。なお，非 圧縮・一次元流れとする.さらに，流路断面積を $S_{f}$ とし， 管に働く軸力 $T$ と内部流によって生じる管内圧力 $p S_{f}$ の合 力 $\Pi=T-p S_{f}$ を定義する.

弾性送水管の $X-Y$ 面内運動を表守無次元支配方程式系 は，無次元量 $u=l u^{*} / \pi, w=l w^{*} / \pi, \Pi=E I \pi^{2} \Pi^{*} / l^{2}, s=l s^{*} / \pi$ 打

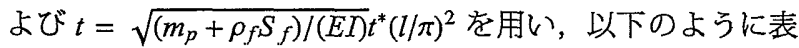
される(7)

$$
\begin{aligned}
& \ddot{u} \cos \theta+\ddot{w} \sin \theta=\Pi^{\prime}+\theta^{\prime} \theta^{\prime \prime}-\sqrt{\beta} \dot{V}+\gamma \cos \theta \\
& -\ddot{u} \sin \theta+\ddot{w} \cos \theta=\Pi \theta^{\prime}-\theta^{\prime \prime \prime}-V^{2} \theta^{\prime}-2 \sqrt{\beta} V \dot{\theta}-\gamma \sin \theta \\
& w^{\prime}=\sin \theta \\
& u^{\prime}=\cos \theta-1 \\
& \text { B.C. }\left\{\begin{array}{l}
s=0: u=0, w=0, \quad \theta=0 \\
s=\pi: u=-\pi, w=2 r, \theta=\pi
\end{array}\right.
\end{aligned}
$$

ここでう， $O^{\prime}$ はそれぞれ $t$ と $s$ 微分を表す。また，式 (1) (5) およびこれ以降は無次元量を表す*は省略する.

式(1) (5) の未知数 $\theta, u$ および $w$ は独立変数 $s, t$ と, 四つの 無次元パラメータである管内定常流速 $V_{s}=v_{s} / \sqrt{\pi^{2} E I / \rho_{f} S_{f}{ }^{2}}$, 管および管内流体の質量に対する管内流体の質量の比 $\beta=\rho_{f} S_{f} /\left(m_{p}+\rho_{f} S_{f}\right)$, 重力と管の弾性力の比 $\gamma=\left(m_{p}+\right.$ $\left.\rho_{f} S_{f}\right) g l^{3} / E I \pi^{3}$, 無次元半径 $r=\pi R / l$ で表される.

\section{3. 静的釣り合い状態}

式(1) (4)において重力によるたわみを考慮するため，時

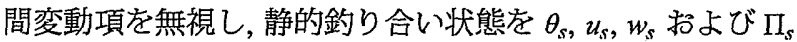
とする. 時間変動項を無視した式 (1), (2)より $\theta_{s}$ を表す方程 式は以下のようになる。

$$
\begin{aligned}
\theta_{s}^{\prime \prime \prime} & -\left(\Pi_{s}(0)-V_{s}^{2}\right) \theta_{s}^{\prime}+\gamma \sin \theta_{s} \\
& =\frac{1}{2} \theta_{s}^{\prime 2}(0) \theta_{s}^{\prime}-\frac{1}{2} \theta_{s}^{\prime 3}-\gamma \theta_{s}^{\prime} \int_{0}^{s} \cos \theta_{s} d s
\end{aligned}
$$

式 (6)において重力の影響を無視すると， $\Pi_{s}(0)=V_{s}^{2}$ のとき， 送水管の静的釣り合い状態は $\theta_{s}(s)^{\prime}=\theta_{c}(s)^{\prime}=1$ (const), つま り，曲率が一定の形状，すなわち半円形となるため，管に重 力が働く場合, 曲率が一定の形状，すなわち半円形状から静 的釣り合い状態が微小に変化していると考える.

そこで, $\theta_{s}=\theta_{c}+\theta_{g}, w_{s}=w_{c}+w_{g}$ 抽よび $\Pi_{s}(0)=V_{s}^{2}+\Pi_{g}(0)$ と置き，静的釣り合い状態への重力の影響を考える.ここで 添え字 $c$ は半円形状を表し, $g$ は半円形状からのたわみを表 す.これらを式 (1) (3) に代大し, $\theta_{g}$ が微小としてその 2次 以上の項を無視すると以下の式を得る.

$$
\begin{aligned}
\theta_{g}^{\prime \prime \prime} & -\left(\Pi_{g}(0)-1\right) \theta_{g}^{\prime}+\gamma \theta_{g}^{\prime} \sin s-\theta_{g}^{\prime}(0) \\
& +\gamma \theta_{g} \cos s-\gamma \int_{0}^{s} \theta_{g} \sin s d s=\Pi_{g}(0)-2 \gamma \sin s
\end{aligned}
$$

$w_{g}^{\prime}=\theta_{g} \cos s$

$$
\text { B.C. } \begin{cases}s=0: w_{g}=0, & \theta_{g}=0 \\ s=\frac{\pi}{2}: w_{g}=0, & \theta_{g}=0\end{cases}
$$


ここで，式 (7) は積分形を含む，変数係数の常微分方程式で あるため，解析的に解くことが非常に困難である. そこで， $\theta_{g}$ を以下のように $s$ にいてのべき級数展開を用いて表す.

$$
\theta_{g}=a_{0}+a_{1} s+a_{2} s^{2}+\cdots+a_{n} s^{n}
$$

式 (10) を式 (7) に代大し, $s^{n}$ の係数を比較すると， $a_{n}(n \geq 3)$ は以下のように定まる。

$n$ が偶数の場合:

$$
\begin{aligned}
a_{n+3} & =\frac{\Pi_{g}(0)-1}{(n+3)(n+2)} a_{n+1} \\
& -\frac{\gamma}{(n+3)(n+2)}\left\{\sum_{k=1}^{n / 2} \frac{(-1)^{k-1}}{(2 k-1) !} a_{n-2(k-1)}\right. \\
& \left.+\frac{1}{(n+1) n} \sum_{k=1}^{(n-2) / 2} \frac{(-1)^{k-1}}{(2 k-1) !} a_{n-2-2(k-1)}\right\}
\end{aligned}
$$

$n$ が奇数の場合:

$$
\begin{aligned}
a_{n+3} & =\frac{\Pi_{g}(0)-1}{(n+3)(n+2)} a_{n+1} \\
& -\frac{\gamma}{(n+3)(n+2)}\left\{\sum_{k=1}^{(n+1) / 2} \frac{(-1)^{k-1}}{(2 k-1) !} a_{n-2(k-1)}\right. \\
& \left.+\frac{1}{(n+1) n} \sum_{k=1}^{(n-1) / 2} \frac{(-1)^{k-1}}{(2 k-1) !} a_{n-2-2(k-1)}\right\} \\
& -\tilde{z} \gamma \frac{(-1)^{(n-1) / 2}}{(n+3) !}
\end{aligned}
$$

なお， $a_{0}, a_{1}$ および $a_{2}$ は境界条件 (9) より求めることがで きる.

図 2 に重力の影響により半円状態からたわんだ状態への 変化を示す. 同図より $s$ がおよそ $\pi / 6$ 付近では半円に対し上 方内側に大り込むことがわかる，また，执よそ $\pi / 4$ 付近で は水平方向内側に大り达み, $\pi / 4 \sim \pi / 2$ にかけては下方外側 にたわんでいることがわかる．また，実験值より $u_{g}=0.032$, $\Pi_{g}(0)=6.31$ とした.

\section{4. 面内振動}

末知数 $\theta, u, w$ およよび П が静的釣り合い状態 $\theta_{s}, u_{s}, w_{s}$ およ び $\Pi_{s}$ から微小に変動したと考え，静的釣り合い状態からの 変位を表す式に書き直す。ここで $\gamma=0$ の場合を考えると， 前節で述べたように静的釣り合い状態はほぼ半円形と見な せるため, $\theta=\theta_{c}+\theta_{d}(s, t), w=w_{c}+w_{d}(s, t), u=u_{c}+u_{d}(s, t), \Pi=$ $\Pi_{c}+\Pi_{d}(s, t)$ と表せる. 添え字 $d$ は静的釣り合い状態からの

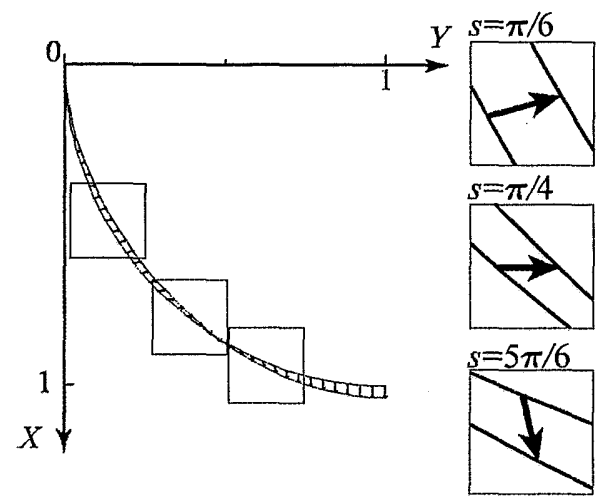

Fig.2 Static Equilibrium State
変動分を表す．なお，管内流速 $V$ は脈動流成分を含んでお り,次式で表される。

$$
V=V_{s}(1+\varepsilon \sin \gamma t)
$$

ここで $\varepsilon(<<1)$ は脈動流成分の大きさを表す．脈動流成分 が送水管の面内運動へ与える影響を考えるために，無次元パ ラメータとして, 無次元の脈動流成分の振幅 $\varepsilon=\Delta v / v_{s}$ およ び脈動流成分の振動数 $v=N \sqrt{\left(m_{p}+\rho_{f} S_{f}\right) / E I}\left(l^{2} / \pi^{2}\right)$ を導入

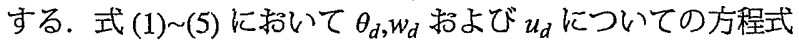
に書き換えると以下のようになる。

$$
\begin{aligned}
& \ddot{u}_{d} \cos s+\ddot{w}_{d} \sin s=\Pi_{d}^{\prime}+\theta_{d}^{\prime \prime}-\sqrt{\beta} V_{s} \varepsilon v \cos v t \\
& -\ddot{u}_{d} \sin s+\ddot{w}_{d} \cos s=\Pi_{d}-\theta_{d}^{\prime \prime \prime}-2 \varepsilon V_{s}^{2} \sin v t-2 \sqrt{\beta} V_{s} \dot{\theta}_{d} \\
& w_{d}^{\prime}=\theta_{d} \cos s \\
& u_{d}^{\prime}=-\theta_{d} \sin s \\
& \text { B.C. } \begin{cases}s=0: u_{d}=0, & w_{d}=0, \theta_{d}=0 \\
s=\pi: u_{d}=0, & w_{d}=0, \theta_{d}=0\end{cases}
\end{aligned}
$$

式 (14) の右辺第 3 項は非同次項であり，管内流に脈動流成 分が含まれることにより発生する強制力項である.

\section{$4 \cdot 1$ 自由振動}

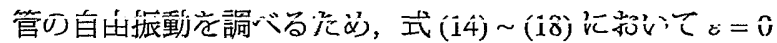
とする. 式 (14), (15) より $\Pi_{d}$ を消去する. 複素固有関数, 複 素固有值をそれぞれ $\Phi_{d}(s), \lambda$ と置き, $\theta_{d}=\Phi_{d}(s) e^{\lambda t}$ とし, 固 有值問題を考える. 式 $(14) \sim(18)$ を満たすように, 固有関数 $\Phi_{d}$ を以下のようにべき級数展開を用いて表す.

$$
\Phi_{d}=a_{0}+a_{1} s+a_{2} s^{2}+\cdots+a_{n} s^{n}
$$

また，複素固有值 $\lambda$ は形式的に以下のような方程式で表 せる。

$$
f\left(\lambda ; V_{s}, \beta\right)=0
$$

複素固有値 $\lambda$ は $i\left(\omega_{r}+i \omega_{i}\right)$ と表せ, 実部 $\omega_{r}$ は管の面内振動の 固有振動数に相当し，虚部 $\omega_{i}$ は減衰率に相当する. 式 (20) を数值的に解き, $\lambda$ を求めた。

図 3 に定常流速 $V_{s}$ の増加に伴う一次モードの固有振動数 $\omega_{r}$ の変化を示す． $V_{s}$ が増加するに従い， $\omega_{r}$ は減少してい る. また, $\omega_{i}$ は0であった. なお, 同図より本研究の解析結 果がMisra ら (2) の結果と㢃好に一致していることがわかる。

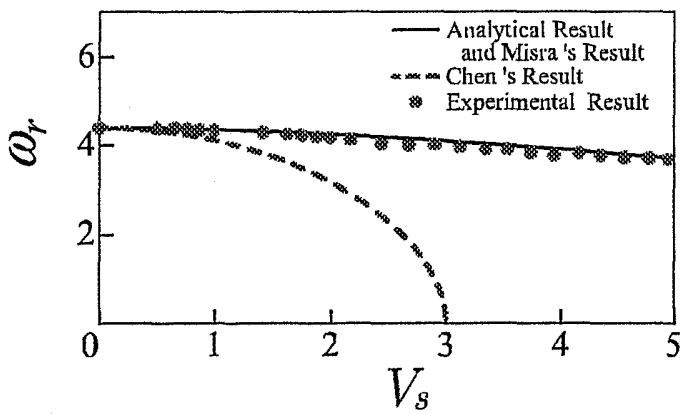

Fig.3 Natural Frequency of First Vibration Mode as a Function of $V_{s}$ 


\section{$4 \cdot 2$ 管内脈動流による強制振動}

管内流に脈動流成分が含まれると，式 (14) に示すように 非定常流体力項 $\sqrt{\beta} V_{s} \varepsilon v \cos v t$ が存在する. そこで式 (14) (18) の解を以下のように仮定する。

$$
\theta_{d}=A(s) \sin v t+B(s) \cos v t
$$

式 (14) （18) に式 (21) を代入すると， $A(s), B(s)$ についての 微分方程式が得られる. その式から, $A(s)$ および $B(s)$ をべき 級数を用いて解くと水平方向変位 $w_{d}$ は以下のように表さ れる。

$$
w_{d}(s, t)=\sqrt{W_{A}^{2}+W_{B}^{2}} \sin (v t+\phi)
$$

ここで, 振幅 $\sqrt{W_{A}^{2}+W_{B}^{2}}$ および 位相差 $\phi(s)$ は $s$ 関数で ある。

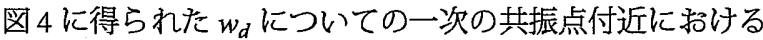
周波数応答曲線を示す. 一次の固有振動数付近 $v=4.14$ に おいて振幅は最大となり，ここでは減衰を考慮していないた め振幅は発散している. 図 5 は共振点付近 $v=4.14$ におけ る曲管の振動形状を表している。これらは一次の固有振動 状態での解析結果とよく一致している．また，計算には実験 值である $\beta=0.21 ， \varepsilon=0.05$ 抿よび $V_{s}=2.62$ を用いた。

数值計算の結果, 求められた解を $A(s), B(s)$ についての微 分方程式に代入した結果， $A(s), B(s)$ それぞれについての誤 差は図 6 に示すように $10^{-10}$ 程度であった。

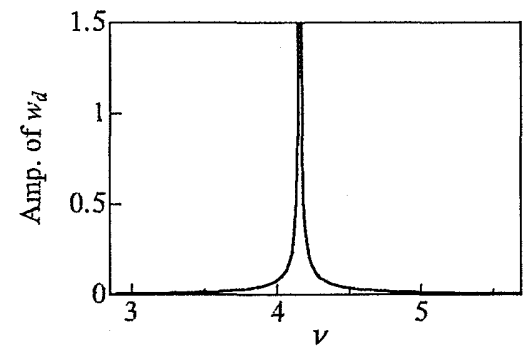

Fig.4 Frequency Response Curves of Amplitude of $w_{d}$ ( $s=$ $\pi / 2, V_{s}=2.62, \beta=0.21, \varepsilon=0.05$ )

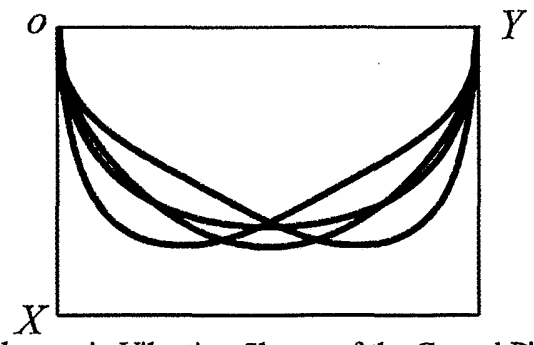

Fig.5 Stroboscopic Vibration Shapes of the Curved Pipe Associated with Primary Resonance of First Vibration Mode $(v=4.14)$

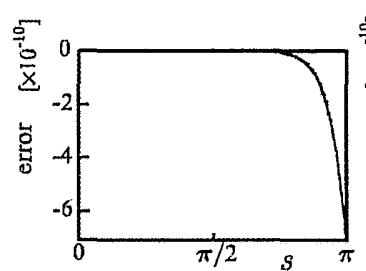

(A)

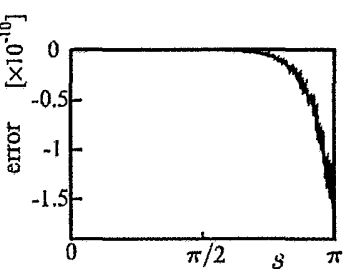

$(B)$
Fig.6 Numerical Errors of Equations governing A and B

\section{$5 \cdot 1$ 実験装置系}

\section{5. 実験}

実験には図 7 に示す装置を用いた．管は内径 $4 \mathrm{~mm}$ ，外径 $8 \mathrm{~mm}$ のシリコンチューブを用い, 両端間距離 $450 \mathrm{~mm}$, 全長 $707 \mathrm{~mm}$ になるように設置した。弾性送水管の変位は，三次 元リアルタイム動作解析システム Quick MAG System を用い て非接触で測定した。 内部流の流速は, 電磁流量計からの電 気信号を FFT アナライザで読み取ることにより測定した。

\section{$5 \cdot 2$ 静的釣り合い状態}

図 8 に，弾性送水管の静的釣り合い状態における写真を 示す. 図には半円形を破線で書いている. $s$ が $0 \sim \pi / 4$ では 半円よりも内側に入り, $s$ が $\pi / 4 \sim \pi / 2$ では半归よりも外側に なっており，理論解析により求めた形状 (図 2) とよく一致し ている.

\section{$5 \cdot 3$ 自由振動}

定常流速 $v_{s}$ が送水管の面内振動の固有振動数に与える影 響を調べた. 定常流速 $v_{s}$ を変化させ，それぞれの流速におい て面内方向に一次モードに近い初期変位を与えて自由振動 させた，定常流速 $v_{s}=4.5 \mathrm{~m} / \mathrm{s}$ に打ける鉛直方向成分 $u_{d}$ ，水 平方向成分 $w_{d}$ の時刻暦と周波数分析結果を図 9 に示す。管 の一次モードでの固有振動数は $X$ 方向, $Y$ 方向ともに $2.1 \mathrm{~Hz}$ であり, 同図の変位 $u_{d}$ および $w_{d}$ の時刻歴から固有周期を読 み取ることにより求めた。

また, 図 3 に流速の増加に伴う一次モードの固有振動数の 変化它示した。解析結果と良好に一致している。
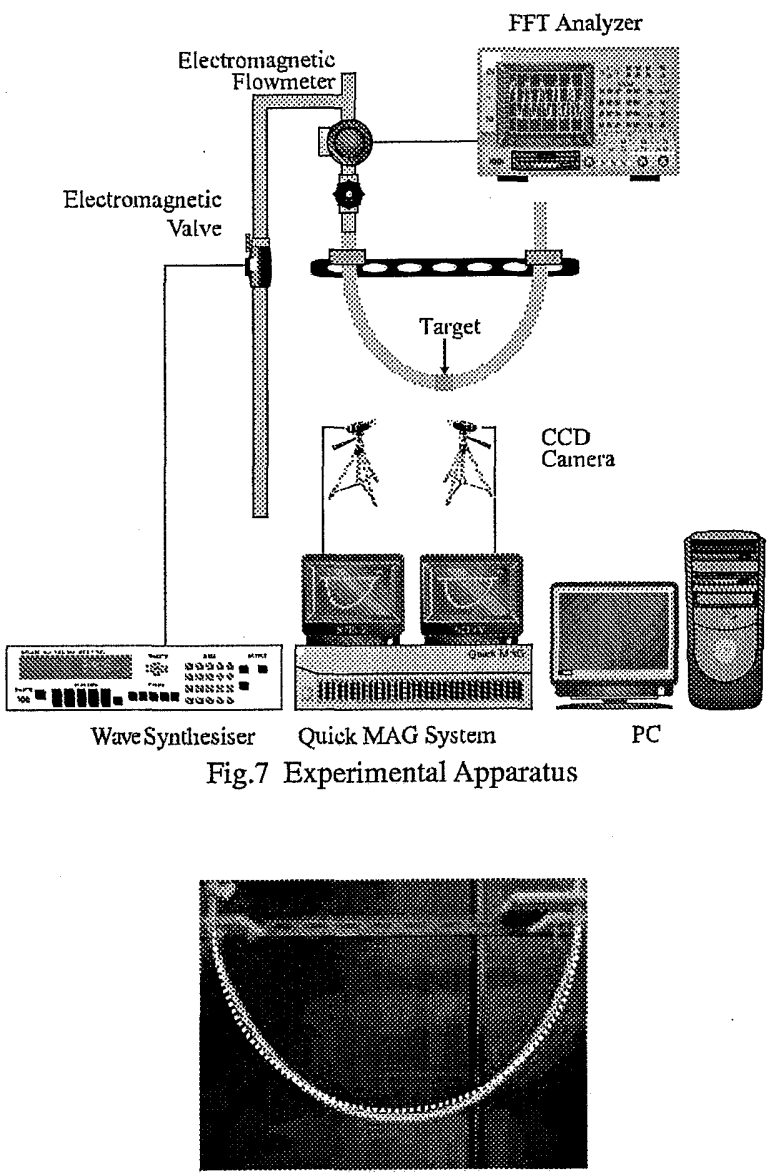

Fig.8 Photograph of the Static Equilibrium State 

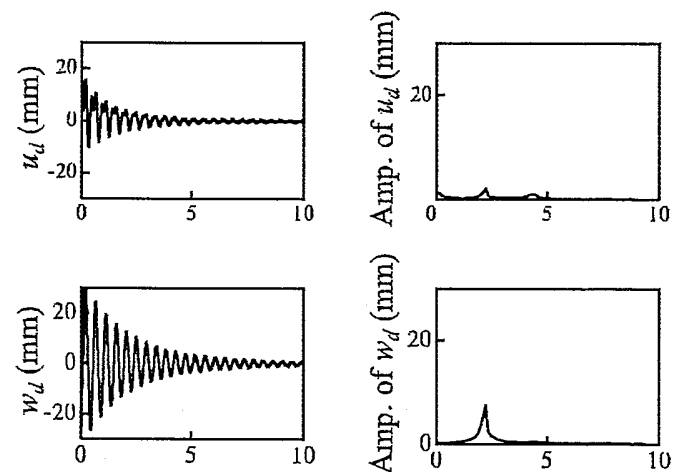

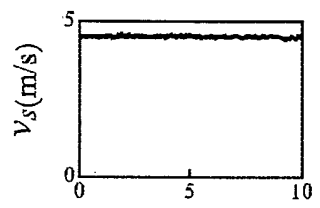

Time(sec)

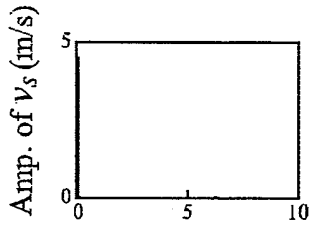

Freq.(Hz)
Fig.9 Free Vibration at Point B

\section{$5 \cdot 4$ 強制振動}

脈動流の振動数 $N$ を $1.7 \mathrm{~Hz}$ から $3.0 \mathrm{~Hz}$ の範囲で上昇させ た. $s=\pi / 2, N=1.9 \mathrm{~Hz}$ での管の鉛直方向変位 $u_{d}$, 水平方向 変位 $w_{d}$ および脈動成分 $\Delta v$ の時刻歴とその周波数分析結果 を図 10 に示す。 $N=1.9 \mathrm{~Hz}$ における振動形状の写真を図 11 に示す．ここで $v_{d}$ は送水管の面外方向の変位を示しており, 管は面外方向には振動していないことが確認できる。また， $s=\pi / 2$ において管の振動は水平方向が支配的であることも 確認できる. 脈動流成分の振動数とほぼ同じ振動数で管は 振動していることから，管は脈動流に起因した強制力を受け て面内振動していることが分かる. $s=\pi / 2$ に和ける，水平 方向成分 $w_{d}$ の振幅の周波数応答は図 12 のとおりである. は脈動流の振動数と同じ振動数成分の振幅であり,。は 2 倍 の振動数成分の振幅である. 脈動流の振動数 $N$ を上昇させた 場合，面内振動の振幅が大きくなり， $N$ が $2.1 \mathrm{~Hz}$ で両者は最 大となることが分かる.このことから，1 次モードの固有振 動数である $N=2.1 \mathrm{~Hz}$ 付近において共振点を迎えているこ とがわかる。

\section{6. 結論}

本研究では，管内脈動流に起因する弾性送水管曲管部の面 内振動の励振メカニズムを解明する第一歩として，これまで 考慮に大れていなかった重力を含んだ曲管の平面運動を支 配する方程式を誘導した，次に，静的釣り合い状態を求め, 曲管の面内振動について, 理論解析および実験を行った。 そ の結果, 以下の結論を得た。

・管内流による曲管の平面運動を，今まで考慮されていな かった静的釣り合い状態における重力の影響を考慮し， 管の中心軸は伸びないという仮定のもと，管軸方向，鉛 直方向, 水平方向变位および管軸と水平方向軸とのなす 角度で表される非線形項を含む方程式で表した。

- 得られた方程式の時間変動項を無視し，静的釣り合い状 態を表す方程式を導出した.また， $\gamma=0$ のとき，管の 形状は管にかかる軸力を調節することで，管の両端間の 距離を直径とする半円形になることを確認した。
- 静的釣り合い状態を半円形とそれからの変動成分との和 で表し，変動成分についての方程式，すなわち積分形を 含む線形変数係数の常微分方程式で表した. 得られた方 程式の解をべき級数展開により求め, 重力が管の静的釣 り合い状態に与える影響を確認した。
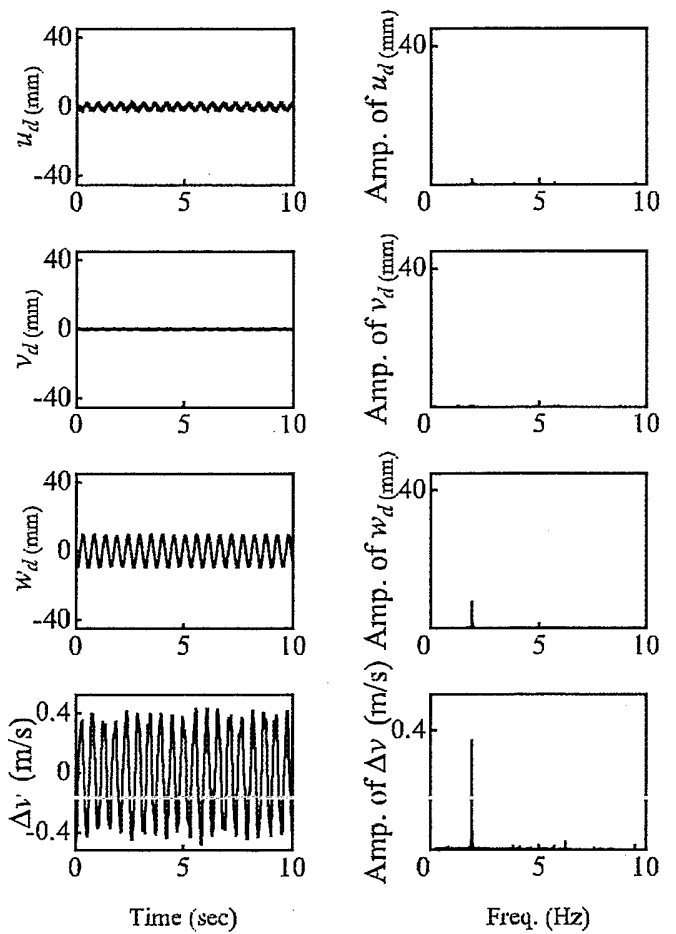

Fig.10 Time Histories of $u_{d}, v_{d}$ and $w_{d}$ and Their Spectra

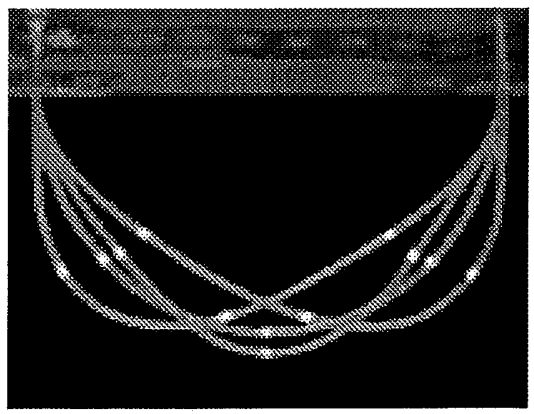

Fig.11 Photograph of the In-plane Pipe Vibration for the 1st Mode

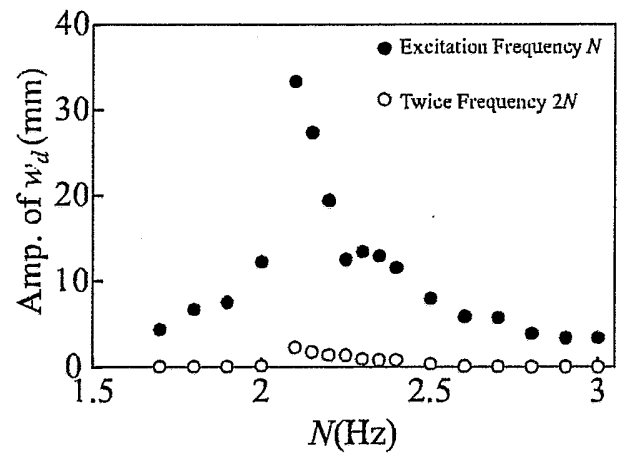

Fig.12 Frequency Response Curves of the Forced Vibration 
- 管の面内自由振動について，管内定常流速が管の固有振 動に与える影響を明らかにした。 また，一次モードの振 動形状を求めた。

- 管内脈動流による曲管の面内振動において $v$ が管の固 有振動数付近で振動振幅が最大となり，また，その振動 モードは固有振動状態での解析結果とよく一致した。

さらに，シリコンチューブに水を流した実験を行い，管の 静的釣り合い状態，管の面内自由振動就よび管内脈動流によ る管の面内振動について理論解析結果の確認を行った。そ の結果を以下に示す。

・自由振動実験により，曲管の振動モードを確認した。 ま た，管内定常流速の増加にともない，管の固有振動数は 減少することを確認した。

- 流速に脈動流成分を付加した場合に，曲管は脈動流成分 と同じ振動数で振動していることから，送水管は管内に 脈動流が流れることにより，強制振動していることを確 認した。

- 脈動流成分の振動数が固有振動数付近において最も励振 された．また，そのときほぼ水平方向に振動しているこ とを確認した.

\section{文 献}

(1) Chen, S. S., Out-of-Plane Vibration and Stability of Curved Tubes Conveying Fluid, Journal of Applied Mechanics, 95, (1973), 362-368.

(2) Misra, A. K., Païdoussis, M. P. and Van, K. S., On the Dynamics of Curved Pipes Transporting Fluid Part I : Inextensible Theory, Journal of Fluids and Structures, 2, (1988), 221-244.

(3) Misra, A. K., Païdoussis, M. P. and Van, K. S., On the Dynamics of Curved Pipes Transporting Fluid Part II : Extensible Theory, Journal of Fluids and Structures, 2, (1988), 245-261.

(4) Dupuis, C., Rousselet, J., The Equation of Motion of Curved Pipes Conveying Fluid, Journal of Sound and Vibration, 153, (1992), 473-489.

（5）田中 慎太郎, 管内脈動流に起因した弾性送水管曲管部の 面外振動，慶應義塾大学修士論文, (2003).

(6) 高橋和雄, 田川賢, 池田 虎彦,ケーブルの面内非線形分 岐応答解析, 土木学会論文集, I-1 (1984), 333-340.

(7) 新谷 智史, 管内流に起因する弾性送水管曲管部の面内振 動 (重力の影響を考慮した場合), 慶應義塾大学修士論文, (2004). 